\title{
Nature's Swiss Army Knife: The Diverse Protective Roles of Anthocyanins in Leaves
}

\author{
Kevin S. Gould* \\ School of Biological Sciences, University of Auckland, Private Bag 92019, Auckland, New Zealand
}

Received 28 June 2004; accepted 15 July 2004

\begin{abstract}
Anthocyanins, the pigments responsible for spectacular displays of vermilion in the leaves of deciduous trees, have long been considered an extravagant waste of a plant's resources. Contemporary research, in contrast, has begun to show that the pigments can significantly influence the way a leaf responds to environmental stress. Anthocyanins have been implicated in tolerance to stressors as diverse as drought, UV-B, and heavy metals, as well as resistance to herbivores and pathogens. By absorbing high-energy quanta, anthocyanic cell vacuoles both protect chloroplasts from the photoinhibitory and photooxidative effects of strong light, and prevent the catabolism of photolabile defence compounds. Anthocyanins also mitigate photooxidative injury in leaves by efficiently scavenging free radicals and reactive oxygen species. Far from being a useless by-product of the flavonoid pathway, these red pigments may in some instances be critical for plant survival.
\end{abstract}

\section{INTRODUCTION}

It is no coincidence that the leaves of most higher plants are green. Chlorophyll and the associated accessory pigments allow plants to maximise use of the visible light spectrum for photosynthesis [1]. By establishing internal gradients in light capture, the green pigments enable plants to respond rapidly to changes in the spectral environment, as well as to exploit niche habitats. Equally, they provide some protection against photoinhibition and photooxidation, the damaging effects of excess quanta. Green leaves are engineered to optimise productivity.

Given the obvious benefits to their being green, why then do many plant species produce red-pigmented leaves at one or more stages in their life cycles? Red-leafed flora are common throughout all orders of the plant kingdom, from the basal liverworts to the most advanced angiosperms [2]. They occur in habitats as diverse as the Antarctic shoreline and the tropical rainforests, are as abundant in arid deserts as in freshwater lakes, and seem equally at home in the light-starved forest understorey as in the sun-drenched canopy. In many red-leafed species the manufacture of red pigments is transient, often associated with a discrete developmental stage such as in the growth flushes of tropical trees $[3,4,5]$, or in the senescing autumn foliage of deciduous trees $[6,7,8,9]$. In certain other species, however, red pigments can persist throughout the leaf's entire life span [10], or else they are induced and retained only after the plant has experienced stress [11]. Functional implications of these red pigments in plants have been the focus of a significant research output over the past decade.
For most vascular plants, red colouration in leaves is achieved by anthocyanins, predominantly cyanidin-3$\mathrm{O}$-glucoside, as a solution located in the vacuole of the plant cell. Other pigments-notably the betalains, certain carotenoids, thiarubrine A, some terpenoids, and the 3deoxyanthocyanins-also impart reddish colours in various species; these pigments have been less well studied than the anthocyanins, but at least some of them have comparable functions in leaves $[12,13,14,15,16]$.

The synthesis and vacuolar sequestration of anthocyanin molecules represent a considerable metabolic investment for plant cells. First, there are metabolic costs associated with enzyme production and activity; at least seven enzymes are involved in the biosynthesis of cyanidin from its precursors, 4-coumaroyl-CoA and malonyl-CoA [17]. Then there is a cost associated with the conjugation of each cyanidin molecule to a monosaccharide molecule. Finally, there are costs associated with the transport of cyanidin-3-O-glucoside into the cell vacuole via a tonoplast Mg-ATP-requiring glutathione carrier [18]. This investment suggests that the accumulation of anthocyanins in leaf cells is unlikely to be an "extravagancy without a vital function" [19]. Neither is it likely that these red pigments are simply the default product of a saturated flavonoid biosynthetic pathway, since the timing of anthocyanin production is usually tightly controlled and often occurs in tissues remote from those associated with other flavonoids [10]. On the contrary, a wealth of recent evidence, both empirical and theoretical, ascribes a remarkable diversity of functions to anthocyanins in leaves, many of them associated with stress responses and some potentially critical to a plant's survival. Anthocyanins are 
arguably the most versatile of all pigments, their multifarious roles in plant stress responses stemming as much from the physicochemical property of light absorption as from their unique combination of biochemical reactivities. Recent advances in our understanding of these various functions are the subject of this review.

\section{CONSEQUENCES OF BEING RED}

Anthocyanins in vivo absorb the green and yellow wavebands of light, commonly between 500 and $600 \mathrm{~nm}$ [20, 21, 22, 23, 24, 25]. Foliage appears red because of the subtraction of yellow-green light from the spectrum of light reflected from the leaf's surface. Interestingly, the amount of red light that is reflected from red leaves often only poorly correlates to anthocyanin content [20]; leaf morphology and the amount and distribution of chlorophyll are apparently the stronger determinants of red reflectance. The property of anthocyanins to absorb light provides a mechanism for several important functions in leaves.

\section{Herbivory}

The red colours of anthocyanic leaves have been proposed both to attract and to repel various animal species. Burns and Dalen [26] postulated that red-orange autumn foliage of Canadian shrub species would accentuate the conspicuousness of black-coloured fruits to birds. Experimental manipulations of fruit and background foliage colours confirmed that the black-red contrast was indeed an effective enhancer of fruit-removal rates by avian dispersers. Certain insects, on the other hand, seem to preferentially avoid eating red-pigmented leaves. California maple aphids, for example, readily colonise yellow-orange leaves of Japanese maples, yet they largely ignore redleafed individuals [27]. Similarly, leaf-cutting ants from the tropical forests of Panama browse significantly less on red leaves than on green leaves [28]. To these and other insects the anthocyanins may serve as aposematic signals of defensive commitment against herbivory [29]. Alternatively, the red pigments may simply render the leaves unpalatable. Leaves that are rich in chlorophyll as well as anthocyanin tend to be brown or even black, mimicking dead foliage or else serving to camouflage leaves against the exposed soil and litter of forest floors [30, 31, 32, 33]. Even brilliant red or scarlet leaves can appear dark to nonmammalian folivores, which lack red light receptors $[5,34]$. The gains to be had from herbivore deterrence would offset metabolic costs to the plant associated with anthocyanin biosynthesis.

\section{Protection of photolabile defence compounds}

By intercepting the high-energy quanta, anthocyanic cell vacuoles can prevent important photolabile molecules from degradation by green light. An elegant example of this was described recently for the silver beachweed ( $A m$ - brosia chamissonis), a composite that grows at exposed, sunny locations along the California coast. The plant holds large amounts of thiarubrine A, a potent defence compound that is toxic to insects, bacteria, and fungi [35]. Thiarubrine A is photolabile; even short exposures to visible light and/or ultraviolet radiation render it inactive $[36,37]$. However, the tissues in A chamissonis that contain thiarubrine A are shielded from light by a sheath of cells containing a mix of two anthocyanins, cyanidin-3$\mathrm{O}$-glucoside and cyanidin-3-O-(6'-O-malonylglucoside). The anthocyanins absorb quanta that would otherwise lead to the destruction of thiarubrine A, and thereby contribute significantly to the defensive armoury of the plant.

\section{Protection of photosynthetic apparatus}

When leaves receive more light energy than can be used in photochemistry, they show a characteristic decline in the quantum efficiency of photosynthesis, termed photoinhibition [38]. Under severe conditions the chloroplasts generate reactive oxygen species, which have the potential to destroy thylakoid membranes, damage DNA, and denature proteins associated with photosynthetic electron transport. Anthocyanins have been shown in many plant species to reduce both the frequency and severity of photoinhibition, as well as to expedite photosynthetic recovery $[23,39,40,41,42,43,44]$. In redosier dogwood (Cornus stolonifera), for example, a 30minute exposure to strong white light reduced the quantum efficiency of photosynthesis by $60 \%$ in red leaves, but by almost $100 \%$ in acyanic leaves [23]. When the plants were returned to darkness, the red leaves recovered to their maximum potential after only 80 minutes, yet their acyanic counterparts had not achieved the pretreatment state even after six hours.

Anthocyanins protect leaves from the stress of photoinhibitory light fluxes by absorbing the excess photons that would otherwise be intercepted by chlorophyll $b$. Although red leaves absorb more green light in total, their photosynthetic tissues actually receive fewer quanta than do those of acyanic leaves because the energy absorbed by the cell vacuole cannot be transferred to the chloroplasts [45]. As a result, under light-limiting environments the photosynthetic efficiencies of red leaves are often slightly lower than those for acyanic leaves [4, 22, 45, 46, 47, 48, 49]. Under strong light, however, the anthocyanins serve as a useful optical filter, diverting excess high-energy quanta away from an already saturated photosynthetic electron transport chain. Chloroplasts irradiated with light that has first passed through a red filter have been shown to generate fewer superoxide radicals, thereby reducing the propensity for structural damage to the photosystems [25]. The anthocyanins are therefore clearly a useful supplement to other nonphotochemical quenching mechanisms such as the xanthophyll cycle pigments. Recent studies involving mutants of Arabidopsis thaliana indicate that whereas xanthophylls have a greater role in the protection of plants from short-term 
light stress, the anthocyanins can be the more effective photoprotectants over the long term [50].

The photoprotection hypothesis potentially explains why the leaves of many deciduous trees turn red in the autumn. As leaves senesce, nitrogen associated with their chloroplasts is resorbed into the branches. Anthocyanins would protect the degrading chlorophyll from damaging light levels, thereby restricting the formation of reactive oxygen that could jeopardize the resorptive process $[2,8$, $9,23,51,52]$. Consistent with this hypothesis, nitrogen resorption has recently been shown to be more efficient in wild-type than in anthocyanin-deficient mutants of three woody species [53].

\section{Protection from ultraviolet radiation}

Interest in the flavonoid family has increased in recent years following the observation that these compounds act as sunscreens against potentially damaging UV-B radiation. Foliar anthocyanins have generally been included with other flavonoids in this UV-B protective role. Consistent with this hypothesis, the anthocyanins, particularly when acylated, absorb strongly in the UV region $[54,55]$, are induced or upregulated in plant tissues in response to UV irradiation $[56,57,58,59,60]$, and mitigate DNA damage in UV-B-irradiated cell cultures $[61,62,63]$. Furthermore, certain anthocyanin-deficient mutants of Arabidopsis are hypersensitive to UV-B [64], and red-leafed Coleus varieties retain higher photosynthetic efficiencies after UV irradiation than do green-leafed varieties [49].

Notwithstanding this body of evidence, there is now a growing conviction that foliar anthocyanins cannot be primarily concerned with UV protection. Unlike the colourless flavonoids, the anthocyanins are usually located in the internal mesophyll tissue rather than in the epidermis, the optimal site for UV interception $[33,65]$. Moreover, UV vulnerability often correlates only poorly to anthocyanin content. For example, an Arabidopsis mutant with enhanced sensitivity to UV radiation was found deficient in certain flavonoids, yet it held normal amounts of anthocyanin [66]. Similarly, the responses of Brassica rapa mutants to supplementary UV-B treatment were for the most part independent of anthocyanin levels in the leaves [67]. Indeed, red-leafed plants of petunia (Impatiens) and rice have all been observed to perform significantly worse than their green-leafed counterparts under UV-enriched environments $[68,69,70]$. Hada et al. [71] noted that DNA damage after prolonged UV treatment was substantially greater in purple-leafed rice than in a near-isogenic green line. To repair UV-damaged DNA, plants employ photolyase, an enzyme that uses blue/UV-A light to remonomerise the pyrimidine dimers. The anthocyanins in purple rice prevented the photoactivation of photolyase by absorbing some of the blue/UV-A light incident on the leaves. Thus, any short-term gain from the absorption of UV-B by anthocyanins would be offset by their property to absorb visible light and thereby limit the rate of DNA repair.

\section{FREE RADICAL SCAVENGING}

Anthocyanins diminish the oxidative load in a leaf simply by filtering out yellow-green light, since the majority of reactive oxygen in plant cells is derived from the excitation of chlorophyll. Anthocyanins are, in addition, excellent scavengers of free radicals. Purified solutions scavenge almost all species of reactive oxygen and nitrogen with an efficiency up to four times greater than those of ascorbate and $\alpha$-tocopherol [72, 73, 74]. Recent experimental evidence indicates that this antioxidant potential is indeed utilised by plant cells. In Arabidopsis, for example, strong light and low temperatures caused more lipid peroxidation in anthocyanin-deficient mutants than in wildtype plants [50]. Similarly, upon gamma irradiation, only those Arabidopsis plants that contained both anthocyanin and ascorbic acid were able to grow and flower normally [75].

Microscopic examinations of wounded leaf peels have shown that red-pigmented cells eliminate $\mathrm{H}_{2} \mathrm{O}_{2}$ significantly faster than do green cells [76]. It is not clear, however, whether scavenging occurs predominantly by the red tautomers of anthocyanin found inside the cell vacuole, or else by the colourless tautomers in the cytosol. Both forms have impressive antioxidant potentials $[77,78,79]$. In a model in vitro system, the colourless tautomers of cyanidin 3-(6-malonyl)glucoside were found capable of scavenging up to $17 \%$ of the superoxide radicals generated by irradiated chloroplasts [25]. Given their proximity to the organelle sources of reactive oxygen, it may be that the cytosolic anthocyanins, rather than those in the cell vacuole, provide the greater contribution to antioxidant defence.

The degree to which anthocyanins contribute to the arsenal of low-molecular-weight antioxidants (LMWA) varies among species. In the young, red leaves of Elatostema rugosum, an understorey herb from New Zealand, anthocyanins are the predominant phenolic component of the LMWA pool [78]. In contrast, the redand green-leafed morphs of the canopy tree Quintinia serrata both hold hydroxycinnamic acids as their most concentrated LMWA [79]. Similar differences have been reported across ecotypes of wild-type Arabidopsis [75]. Thus it would seem that anthocyanin biosynthesis can enhance but is not usually a prerequisite for protection from oxidative stress.

\section{AMELIORATION OF STRESS RESPONSES}

The induction of foliar anthocyanins has been implicated in the acquisition of tolerance to many different kinds of environmental stressors [11, 80, 81]. Anthocyanins, for example, are associated with enhanced resistance to the effects of chilling and freezing [82, 83, 84, 85, $86]$, to heavy metal contamination $[87,88,89,90]$, to desiccation $[91,92,93]$, and to wounding $[76,94,95]$. It is not clear at this stage whether the apparent ameliorative properties stem from one or more types of mechanism. Chalker-Scott $[11,80]$ provided a compelling case for 
a generalised role of anthocyanins as osmoregulators in plant cells, since most types of suboptimal environments induce water stress, either directly or indirectly. Others have argued that the photoprotective [96] or the antioxidant [97] properties of anthocyanins are paramount. Regardless of their mechanism, it is clear that anthocyanins offer multifaceted, versatile, and effective protection to plants under stress. They are the Swiss army knife of the plant kingdom.

\section{REFERENCES}

[1] Nishio JN. Why are higher plants green? Evolution of the higher plant photosynthetic pigment complement. Plant Cell Environ. 2000;23(6):539-548.

[2] Lee DW. Anthocyanins in leaves: distribution, phylogeny and development. In: Gould KS, Lee DW, eds. Anthocyanins in Leaves. vol. 37 of Advances in Botanical Research. Amsterdam, The Netherlands: Academic Press; 2002:37-53.

[3] Lee DW, Brammeier S, Smith AP. The selective advantages of anthocyanins in developing leaves of mango and cacao. Biotropica. 1987;19:40-49.

[4] Tuohy JM, Choinski JS. Comparative photosynthesis in developing leaves of Brachystegia spiciformis Benth. J Exp Bot. 1990;41:919-923.

[5] Juniper BE. Flamboyant flushes: a reinterpretation of non-green flush colours in leaves. In: International Dendrology Society Yearbook. London, UK: International Dendrology Society; 1993:49-57.

[6] Koike T. Autumn coloring, photosynthetic performance and leaf development of deciduous broadleaved trees in relation to forest succession. Tree Physiol. 1990;7(1-4):21-32.

[7] Lee DW. Anthocyanins in autumn leaf senescence. In: Gould KS, Lee DW, eds. Anthocyanins in Leaves. vol. 37 of Advances in Botanical Research. Amsterdam, The Netherlands: Academic Press; 2002:147165.

[8] Lee DW, O’Keefe J, Holbrook NM, Feild TS. Pigment dynamics and autumn leaf senescence in a New England deciduous forest, eastern USA. Ecological Research. 2003;18(6):677-694.

[9] Schaberg PG, Van den Berg AK, Murakami PF, Shane JB, Donnelly JR. Factors influencing red expression in autumn foliage of sugar maple trees. Tree Physiol. 2003;23(5):325-333.

[10] Gould KS, Markham KR, Smith RH, Goris JJ. Functional role of anthocyanins in the leaves of Quintinia serrata A. Cunn. J Exp Bot. 2000;51(347):1107-1115.

[11] Chalker-Scott L. Environmental significance of anthocyanins in plant stress responses. Photochem Photobiol. 1999;70(1):1-9.

[12] Stintzing FC, Carle R. Functional properties of anthocyanins and betalains in plants, food, and in human nutrition. Trends in Food Science \& Technology. 2004;15(1):19-38.

[13] Han Q, Shinohara K, Kakubari Y, Mukai Y. Photo- protective role of rhodoxanthin during cold acclimation in Cryptomeria japonica. Plant Cell Environ. 2003;26(5):715-723.

[14] Cohen MF, Meziane T, Tsuchiya M, Yamasaki H. Feeding deterrence of Azolla in relation to deoxyanthocyanin and fatty acid composition. Aquatic Botany. 2002;74(2):181-187.

[15] Schutt C, Netzly D. Effect of apiforol and apigeninidin on the growth of selected fungi. J Chem Ecol. 1991;17:1123-1125.

[16] Stonecipher LL, Hurley PS, Netzley DH. Effect of apigeninidin on the growth of selected bacteria. $J$ Chem Ecol. 1993;19:1021-1027.

[17] Shirley BW. Flavonoid biosynthesis: 'new' functions for an 'old' pathway. Trends Plant Sci. 1996;1 (11):377-382.

[18] Alfenito MR, Souer E, Goodman CD, et al. Functional complementation of anthocyanin sequestration in the vacuole by widely divergent glutathione S-transferases. Plant Cell. 1998;10(7):1135-1149.

[19] Matile P. Biochemistry of Indian summer: physiology of autumnal leaf coloration. Exp Gerontol. 2000;35(2):145-158.

[20] Neill SO, Gould KS. Optical properties of leaves in relation to anthocyanin concentration and distribution. Can J Bot. 1999;77(12):1777-1782.

[21] Woodall G, Dodd I, Stewart G. Contrasting leaf development within the genus Syzygium. J Exp Bot. 1998;49(318):79-87.

[22] Pietrini F, Massacci A. Leaf anthocyanin content changes in Zea mays L grown at low temperature: Significance for the relationship between the quantum yield of PS II and the apparent quantum yield of $\mathrm{CO}_{2}$ assimilation. Photosynth Research, 1998;58(3):213-219.

[23] Feild TS, Lee DW, Holbrook NM. Why leaves turn red in autumn. The role of anthocyanins in senescing leaves of red-osier dogwood. Plant Physiol. 2001;127(2):566-574.

[24] Gitelson AA, Merzlyak MN, Chivkunova OB. Optical properties and nondestructive estimation of anthocyanin content in plant leaves. Photochem Photobiol. 2001;74(1):38-45.

[25] Neill SO, Gould KS. Anthocyanins in leaves: light attenuators or antioxidants? Functional Plant Biology. 2003;30(8):865-873.

[26] Burns KC, Dalen JL. Foliage color contrasts and adaptive fruit color variation in a bird-dispersed plant community. Oikos. 2002;96(3):463-469.

[27] Furuta K. Host preference and population dynamics inan autumnal population of the maple aphid, Periphyllus californiensis Shinji (Homoptera, Aphididae). Journal of Applied Entomology. 1986;102:93100.

[28] Coley PD, Aide TM. Red coloration of tropical young leaves: a possible antifungal defence? Trop Ecol. 1989;5:293-300.

[29] Hamilton WD, Brown SP. Autumn tree colours 
as a handicap signal. Proc $R$ Soc Lond B Biol Sci. 2001;268(1475):1489-1493.

[30] Stone BC. Protective colouration of young leaves in certain Malaysian palms. Biotropica. 1979;11:126.

[31] Blanc P. Biologie des plantes des sous-bois tropicaux [PhD Thesis]. Paris, France: Université Pierre et Marie Curie (Paris 6); 1989.

[32] Givnish TJ. Leaf mottling: relation to growth form and leaf phenology and possible role as camouflage. Functional Ecology. 1990;4(4):463-474.

[33] Lee DW, Collins TH. Phylogenetic and ontogenetic influences on the distribution of anthocyanins and betacyanins in leaves of tropical plants. Int J Plant Sci. 2001;162(5):1141-1153.

[34] Dominy NJ, Lucas PW, Ramsden LW, RibaHernandez P, Stoner KE, Turner IM. Why are young leaves red? Oikos. 2002;98(1):163-176.

[35] Page JE, Towers GH. Anthocyanins protect lightsensitive thiarubrine phototoxins. Planta. 2002;215 (3):478-484.

[36] Block E, Page JE, Toscano JP, et al. Photochemistry of thiarubrine $\mathrm{A}$ and other 1,2-dithiins - formation of 2,6-dithiabicyclo[3.1.0]hex-3-enes. Journal of the American Chemical Society. 1996;118(19):47194720.

[37] Page JE, Block E, Towers GHN. Visible-light photochemistry and phototoxicity of thiarubrines. Photochem Photobiol. 1999;70(2):159-165.

[38] Long SP, Humphries S, Falkowski PG. Photoinhibition of photosynthesis in nature. Annu Rev Plant Physiol Plant Mol Biol. 1994;45:633-662.

[39] Gould KS, Kuhn DN, Lee DW, Oberbauer SF. Why leaves are sometimes red. Nature. 1995;378(6554) :241-242.

[40] Krol M, Gray GR, Hurry VM, Öquist G, Malek L, Huner NPA. Low-temperature stress and photoperiod affect an increased tolerance to photoinhibition in Pinus banksiana seedlings. Can J Bot. 1995;73:1119-1127.

[41] Dodd I, Critchley C, Woodall G, Stewart G. Photoinhibition in differently coloured juvenile leaves of Syzygium species. J Exp Bot. 1998;49(325):14371445.

[42] Smillie RM, Hetherington SE. Photoabatement by anthocyanin shields photosynthetic systems from light stress. Photosynthetica. 1999;36(3): 451-463.

[43] Pietrini F, Ianelli MA, Massacci A. Anthocyanin accumulation in the illuminated surface of maize leaves enhances protection from photo-inhibitory risks at low temperature, without further limitation to photosynthesis. Plant Cell Environ. 2002;25(10): 1251-1259.

[44] Manetas Y, Drinia A, Petropoulou Y. High contents of anthocyanins in young leaves are correlated with low pools of xanthophyll cycle components and low risk of photoinhibition. Photosynthetica. 2002;40(3):349-354.
[45] Gould KS, Vogelmann TC, Han T, Clearwater MJ. Profiles of photosynthesis within red and green leaves of Quintinia serrata. Physiol Plant. 2002;116(1):127-133.

[46] Manetas Y, Petropoulou Y, Psaras GK, Drinia A. Exposed red (anthocyanic) leaves of Quercus coccifera display shade characteristics. Functional Plant Biology. 2003;30(3):265-270.

[47] Barker DH, Seaton GGR, Robinson SA. Internal and external photoprotection in developing leaves of the CAM plant Cotyledon orbiculata. Plant Cell Environ. 1997;20(5):617-624.

[48] Choinski JS Jr, Johnson JM. Changes in photosynthesis and water status of developing leaves of Brachystegia spiciformis Benth. Tree Physiol. 1993;13(1):17-27.

[49] Burger J, Edwards GE. Photosynthetic efficiency, and photodamage by UV and visible radiation, in red versus green leaf coleus varieties. Plant Cell Physiol. 1996;37:395-399.

[50] Harvaux M, Kloppstech K. The protective functions of carotenoid and flavonoid pigments against excess visible radiation at chilling temperature investigated in Arabidopsis $n p q$ and $t$ mutants. Planta. 2001;213(6):953-966.

[51] Garcia-Plazaola JI, Hernandez A, Becerril JM. Antioxidant and pigment composition during autumnal leaf senescence in woody deciduous species differing in their ecological traits. Plant Biology. 2003;5(5):557-566.

[52] Hoch WA, Zeldin EL, McCown BH. Physiological significance of anthocyanins during autumnal leaf senescence. Tree Physiol. 2001;21(1):1-8.

[53] Hoch WA, Singsaas EL, McCown BH. Resorption protection. Anthocyanins facilitate nutrient recovery in autumn by shielding leaves from potentially damaging light levels. Plant Physiol. 2003;133(3):12961305.

[54] Markham KR. Techniques of Flavonoid Identification. London, UK: Academic Press; 1982.

[55] Giusti MM, Rodriguez-Saona LE, Wrolstad RE. Molar absorptivity and color characteristics of acylated and non-acylated pelargonidin-based anthocyanins. J Agric Food Chem. 1999;47(11):4631-4637.

[56] Alexieva V, Sergiev I, Mapelli S, Karanov E. The effect of drought and ultraviolet radiation on growth and stress markers in pea and wheat. Plant Cell Environ. 2001;24(12):1337-1344.

[57] Brandt K, Giannini A, Lercari B. Photomorphogenic responses to UV radiation.3. A comparative study of UVB effects on anthocyanin and flavonoid accumulation in wild-type and aurea mutant of tomato ( $L y$ copersicon esculentum Mill.). Photochem Photobiol. 1995;62:1081-1087.

[58] Mendez M, Gwynn-Jones D, Manetas Y. Enhanced UV-B radiation under field conditions increases anthocyanin and reduces the risk of photoinhibition but does not affect growth in the carnivorous plant 
Pinguicula vulgaris. New Phytol. 1999;144(2):275282.

[59] Reddy VS, Goud KV, Sharma R, Reddy AR. Ultraviolet-B-responsive anthocyanin production in a rice cultivar is associated with a specific phase of phenylalanine ammonia lyase biosynthesis. Plant Physiol. 1994;105(4):1059-1066.

[60] Singh A, Selvi M, Sharma R. Sunlight-induced anthocyanin pigmentation in maize vegetative tissues. J Exp Bot. 1999;50(339):1619-1625.

[61] Takahashi A, Takeda K, Ohnishi T. Light-induced anthocyanin reduces the extent of damage to DNA in UV-irradiated Centaurea cyanus cells in culture. Plant Cell Physiol. 1991;32:541-547.

[62] Kootstra A. Protection from UV-B-induced DNA damage by flavonoids. Plant Mol Biol. 1994;26(2): $771-774$

[63] Stapleton AE, Walbot V. Flavonoids can protect maize DNA from the induction of ultraviolet radiation damage. Plant Physiol. 1994;105(3):881-889.

[64] Li J, Ou-Lee TM, Raba R, Amundson RG, Last RL. Arabidopsis flavonoid mutants are hypersensitive to UV-B irradiation. Plant Cell. 1993;5(2):171-179.

[65] Gould KS, Quinn BD. Do anthocyanins protect leaves of New Zealand native species from UV-B? New Zealand Journal of Botany. 1999;37(1):175-178.

[66] Lois R, Buchanan BB. Severe sensitivity to ultraviolet radiation in an Arabidopsis mutant deficient in flavonoid accumulation. II. Mechanisms of UVresistance in Arabidopsis. Planta. 1994;194:504-509.

[67] Klaper R, Frankel S, Berenbaum MR. Anthocyanin content and UVB sensitivity in Brassica rapa. Photochem Photobiol. 1996;63(6):811-813.

[68] Ryan KG, Markham KR, Bloor SJ, Bradley JM, Mitchell KA, Jordan BR. UVB radiation induced increase in quercetin: kaempferol ratio in wild-type and transgenic lines of Petunia. Photochem Photobiol. 1998;68(3):323-330.

[69] Dixon P, Weinig C, Schmitt J. Susceptibility to UV damage in Impatiens capensis (Balsaminaceae): testing for opportunity costs to shade-avoidance and population differentiation. Am J Bot. 2001;88(8): 1401-1408.

[70] Maekawa M, Sato T, Kumagai T, Noda K. Differential responses to UV-B irradiation of three near isogenic lines carrying different purple leaf genes for anthocyanin accumulation in rice (Oryza sativa L.). Breeding Science. 2001;51:27-32.

[71] Hada H, Hidema J, Maekawa M, Kumagai T. Higher amounts of anthocyanins and UV-absorbing compounds effectively lowered CPD photorepair in purple rice (Oryza sativa L.). Plant Cell Environ. 2003;26(10):1691-1701.

[72] Bors W, Michel C, Saran M. Flavonoid antioxidants: rate constants for reactions with oxygen radicals. Methods in Enzymology. 1994;234:420-429.

[73] Rice-Evans CA, Miller NJ, Paganga G. Antioxidant properties of phenolic compounds. Trends Plant Sci.
1997;2(4):152-159.

[74] Wang H, Cao G, Prior RL. Oxygen radical absorbing capacity of anthocyanins. J Agric Food Chem. 1997;45(2):304-309.

[75] Nagata T, Todoriki S, Masumizu T, et al. Levels of active oxygen species are controlled by ascorbic acid and anthocyanin in Arabidopsis. J Agric Food Chem. 2003;51(10):2992-2999.

[76] Gould KS, McKelvie J, Markham KR. Do anthocyanins function as antioxidants in leaves? Imaging of $\mathrm{H}_{2} \mathrm{O}_{2}$ in red and green leaves after mechanical injury. Plant Cell Environ. 2002;25(10):1261-1269.

[77] Lapidot T, Harel S, Akiri B, Granit R, Kanner J. pHdependent forms of red wine anthocyanins as antioxidants. J Agric Food Chem. 1999;47(1):67-70.

[78] Neill SO, Gould KS, Kilmartin PA, Mitchell KA, Markham KR. Antioxidant activities of red versus green leaves in Elatostema rugosum. Plant Cell Environ. 2002;25(4):539-547.

[79] Neill SO, Gould KS, Kilmartin PA, Mitchell KA, Markham KR. Antioxidant capacities of green and cyanic leaves in the sun species, Quintinia serrata. Functional Plant Biology. 2002;29(12):1437-1443.

[80] Chalker-Scott L. Do anthocyanins function as osmoregulators in leaf tissues? In: Gould KS, Lee DW, eds. Anthocyanins in Leaves. Amsterdam: Academic Press; 2002:103-127. Advances in Botanical Research; Vol. 37.

[81] Close DC, Beadle CL. The ecophysiology of foliar anthocyanin. Bot Rev. 2003;69(2):149-161.

[82] Christie PJ, Alfenito MR, Walbot V. Impact of lowtemperature stress on general phenylpropanoid and anthocyanin pathways: Enhancement of transcript abundance and anthocyanin pigmentation in maize seedlings. Planta. 1994;194:541-549.

[83] McKown R, Kuroki G, Warren G. Cold responses of Arabidopsis mutants impaired in freezing tolerance. J Exp Bot. 1996;47(305):1919-1925.

[84] Nozzolillo C, Isabelle P, Andersen OM, Abou-Zaid M. Anthocyanins of jack pine (Pinus banksiana) seedlings. Can J Bot. 2002;80(7):796-801.

[85] Oberbauer SF, Starr G. The role of anthocyanins for photosynthesis of Alaskan arctic evergreens during snow melt. In: Gould KS, Lee DW, eds. Anthocyanins in Leaves. vol. 37 of Advances in Botanical Research. Amsterdam: Academic Press; 2002:129-145.

[86] Solecka D, Kacperska A. Phenylpropanoid deficiency affects the course of plant acclimation to cold. Physiol Plant. 2003;119(2):253-262.

[87] Hale KL, McGrath SP, Lombi E, et al. Molybdenum sequestration in Brassica species. A role for anthocyanins? Plant Physiol. 2001;126(4):1391-1402.

[88] Hale KL, Tufan HA, Pickering IJ, et al. Anthocyanins facilitate tungsten accumulation in Brassica. Physiol Plant. 2002;116(3):351-358.

[89] Krupa Z, Baranowska M, Orzol D. Can anthocyanins be considered as heavy metal stress indicator in 
higher plants? Acta Physiol Plantarum. 1996;18:147151.

[90] Marrs KA, Walbot V. Expression and RNA splicing of the maize glutathione S-transferase Bronze2 gene is regulated by cadmium and other stresses. Plant Physiol. 1997;113(1):93-102.

[91] Farrant JM. A comparison of mechanisms of desiccation tolerance among three angiosperm resurrection plant species. Plant Ecology. 2000;151(1):29-39.

[92] Farrant JM, Vander Willigen C, Loffell DA, Bartsch $\mathrm{S}$, Whittaker A. An investigation into the role of light during desiccation of three angiosperm resurrection plants. Plant Cell Environ. 2003;26(8):1275-1286.

[93] Sherwin HW, Farrant JM. Protection mechanisms against excess light in the resurrection plants Craterostigma wilmsii and Xerophyta viscose. Plant Growth Regul. 1998;24(3):203-210.

[94] Ferreres F, Gil MI, Castañer M, Tomás-Barberán FA. Phenolic metabolites in red pigmented lettuce ( $\mathrm{Lac}$ tuca sativa). Changes with minimal processing and cold storage. J Agric Food Chem. 1997;45(11):42494254.

[95] Tamari G, Borochov A, Atzorn R, Weiss D. Methyl jasmonate induces pigmentation and flavonoid gene expression in petunia corollas: A possible role in wound response. Physiol Plant. 1995;94(1):45-50.

[96] Steyn WJ, Wand SJE, Holcroft DM, Jacobs G. Anthocyanins in vegetative tissues: a proposed unified function in photoprotection. New Phytol. 2002;155(3):349-361.

[97] Gould KS, Neill SO, Vogelmann TC. A unified explanation for anthocyanins in leaves? In: Gould KS, Lee DW, eds. Anthocyanins in Leaves. vol. 37 of Advances in Botanical Research. Amsterdam: Academic Press; 2002:167-192.

* E-mail: k.gould@auckland.ac.nz

Fax: +64 9 3737417; Tel: +6493737599 



Submit your manuscripts at

http://www.hindawi.com
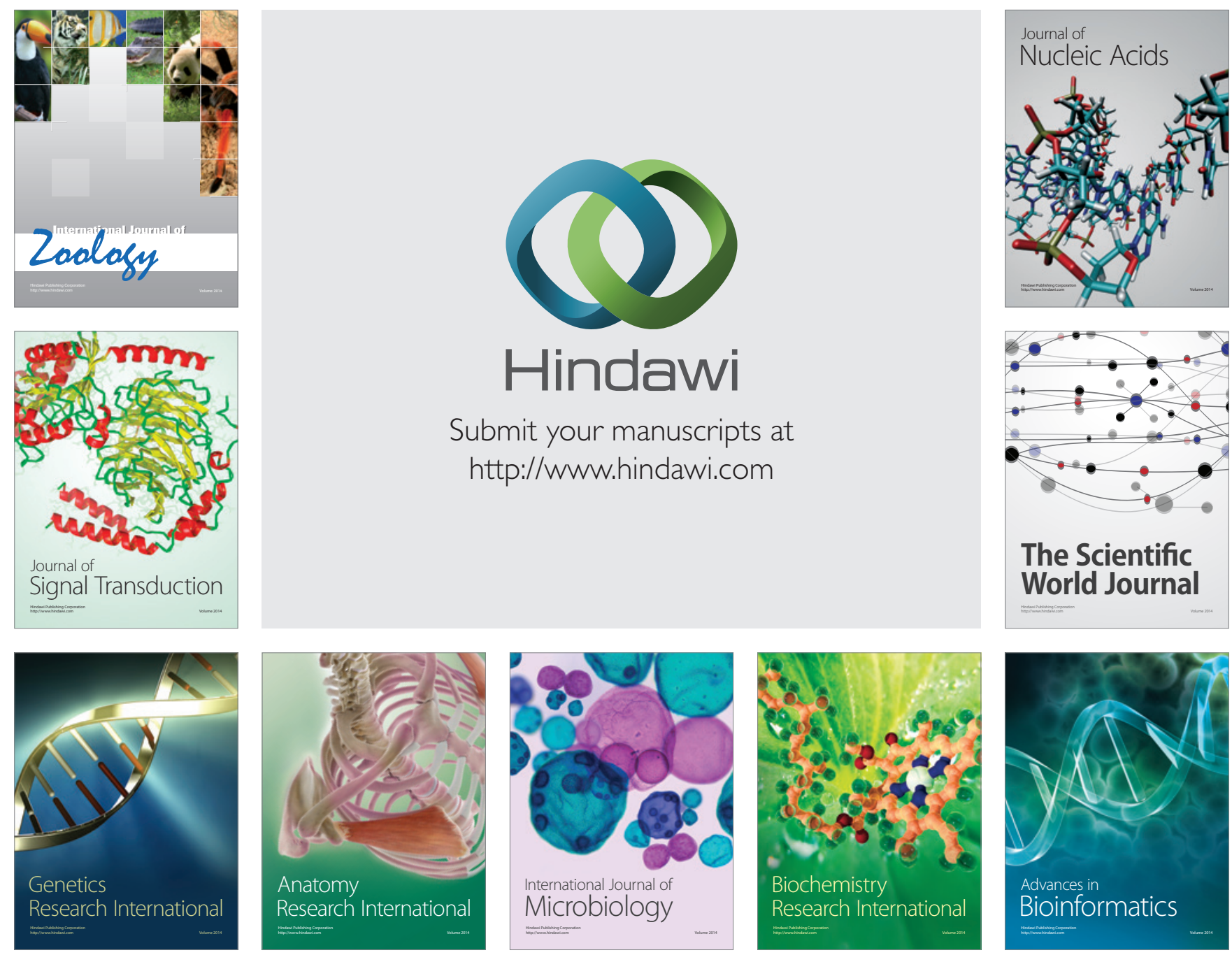

The Scientific World Journal
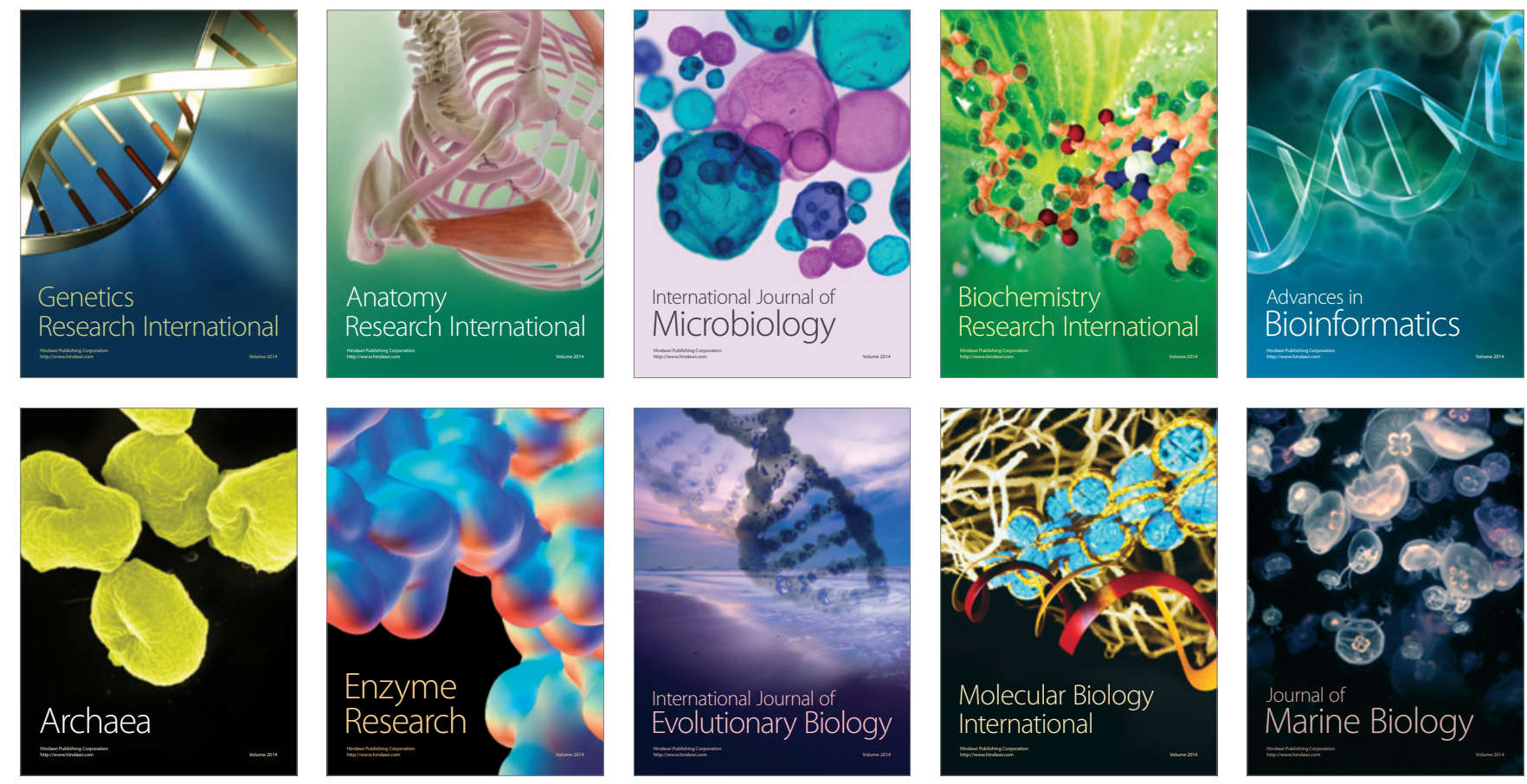